\title{
Streptomyces akiyoshiensis differs from other Gram-positive bacteria in the organization of a core biosynthetic pathway gene for aspartate family amino acids
}

\author{
Yunzheng Le, Jianyong He† and Leo C. Vining \\ Author for correspondence: Leo C. Vining. Tel. +1 902494 2040. Fax: +1 9024943736.
}

Department of Biology, Dalhousie University, Halifax, Nova Scotia, Canada B3H 4J1

\begin{abstract}
A partial Sau3Al digest of genomic DNA from Streptomyces akiyoshiensis was cloned in a Streptomyces-Escherichia coli shuttle vector, and the recombinant plasmids were used to transform E. coli CGSC 6212 , which carries a mutation in the gene for aspartate semialdehyde dehydrogenase (Asd). One of 39000 transformants tested grew on LB medium lacking diaminopimelate. A 17 kb plasmid ( $p J V_{21}$ ) isolated from this strain conferred prototrophy when used to transform E. coli CGSC 6212. The gene responsible was located on a $2.2 \mathrm{~kb}$ DNA fragment by subcloning. Nucleotide sequencing and codon preference analysis of the subcloned insert and of the $3.3 \mathrm{~kb}$ insert in the Asd-complementing plasmid pJV36 located three complete and two incomplete open reading frames (ORFs). One of these (ORF3), encoding a polypeptide of 338 amino acids $\left(M_{r} 35484\right)$, was identified as the gene for Asd by comparing its sequence with database sequences of asd from other bacteria. The inability of pJV30, in which a segment of ORF3 had been deleted, to transform E. coli CGSC 6212 to prototrophy supported this assignment. Southern hybridization indicated that the sequenced region of the cloned DNA fragment represented a continuous segment of the $S$. akiyoshiensis chromosome. The deduced amino acid sequences of the ORFs adjacent to asd showed no similarity to sequences for aspartate kinase (Ask); also, transformation with plasmids containing asd and adjacent regions from the $S$. akiyoshiensis chromosome did not complement the ask mutant E. coli CGSC 5074. It is concluded that asd and ask in S. akiyoshiensis are not present in an operon, and thus are organized differently from these genes in the Gram-positive bacteria previously examined.
\end{abstract}

Keywords: aspartate pathway, aspartate semialdehyde dehydrogenase, Streptomyces akiyoshiensis, asd

\section{INTRODUCTION}

Cultures of Streptomyces akiyoshiensis accumulate 5hydroxy-4-oxonorvaline (HON), a nonprotein amino acid active against tuberculous bacilli (Kanazawa et al., 1960)

\footnotetext{
†Present address: Pharmaceutics Department, Pharmacy University of Shenyang, 103 Wenhua Road, Shenyang 110015, People's Republic of China.

Abbreviations: Asd, aspartate semialdehyde dehydrogenase; Ask, aspartate kinase; DAP, diaminopimelic acid; HON, 5-hydroxy-4oxonorvaline.

The GenBank accession number for the nucleotide sequence reported in this paper is U29446.
}

and some fungi (Yamaguchi et al., 1990). From the pattern of isotope incorporation into the metabolite from labelled aspartate and acetate, White et al. (1988) postulated that the first step in HON biosynthesis is the condensation of an acetate derivative (e.g. acetyl- or malonyl-coenzyme A) with the activated $\beta$-carboxyl of aspartate. Potential forms of aspartate would be aspartyl phosphate or aspartate semialdehyde. Subsequent loss of the acetate-derived carboxyl group would generate HON from the six-carbon $\beta$-keto or $\beta$-hydroxy acid (or thioester) initially formed. Isolation of mutants altered in the biosynthesis of aspartate-family amino acids as well as in HON production supported the conclusion from precursor labelling that aspartate is a key biosynthetic intermediate. Efforts to characterize the mutations indicated that the 


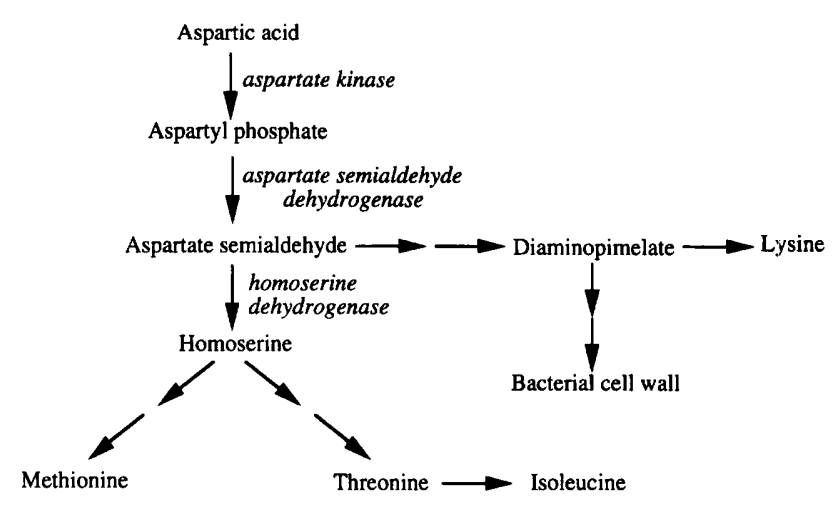

Fig. 1. Biosynthetic pathway for the aspartate family of amino acids.

pathway to HON diverged at an early step from the branching aspartate family pathway, but did not identify the branch-point (Le, 1994).

Amino acids of the aspartate family are synthesized by a similar series of biochemical reactions in all bacteria (Fig. 1 ); in particular, the core pathway from aspartic acid to homoserine is well conserved. However, differences in the regulation of the pathway give rise to multiple forms of some enzymes, and enzyme multiplicity can vary with the organism. In Escherichia coli there are three isozymes of aspartate kinase (Ask), regulated specifically by lysine, methionine or threonine (Theze et al., 1974). In bacilli there are also three Asks, but they are regulated by diaminopimelic acid (DAP), lysine, or lysine and threonine (Zhang et al., 1990). Only one Ask is present in Pseudomonas, brevibacteria and corynebacteria (Shiio \& Miyajima, 1969; Cohen et al., 1969; Cremer et al., 1988). Aspartate semialdehyde dehydrogenase (Asd), which catalyses the conversion of aspartyl phosphate to aspartate semialdehyde, and thus is required for the biosynthesis of DAP, lysine, methionine, threonine and isoleucine, has so far been found in only one form in all micro-organisms examined.

In streptomycetes, where aspartate is a precursor not only of the related protein amino acids but sometimes also of secondary metabolites, there is evidence that regulatory mechanisms acting on core reactions in the aspartate pathway control the flow of metabolic intermediates to such products as the $\beta$-lactam antibiotics, which are derived from lysine via $\mathrm{L}-\alpha$-aminoadipic acid (Whitney et al., 1972; Madduri et al., 1989; Vining et al., 1990). Both Ask and Asd have been partially purified from Streptomyces clavuligerus (Mendelovitz \& Aharonowitz, 1982). Concerted feedback inhibition of Ask was demonstrated with a mixture of lysine and threonine, while lysine alone caused activation. No feedback effects on Asd by pathway end-products have been reported, but the regulation of this and other core enzymes of the aspartate pathway in streptomycetes has not been examined in depth. To better understand the role of the core reactions in the biosynthesis of aspartate family amino acids and related secondary metabolites in S. akiyoshiensis, we have cloned and sequenced the gene for Asd and its adjacent regions.

\section{METHODS}

Micro-organisms, plasmids and media. The characteristics and sources of bacteria, phage and plasmids used are given in Table 1. Streptomyces akiyoshiensis was maintained on maltose/yeast extract/malt extract (MYM) agar (Stuttard, 1982) adjusted to $\mathrm{pH} 7 \cdot 0$. For isolation of genomic DNA, S. akiyoshiensis was grown in a medium containing (per litre): Trypticase Soy Broth (BBL; $30 \mathrm{~g})$, yeast extract $(10 \mathrm{~g})$, sucrose $(100 \mathrm{~g})$ and $\mathrm{MgCl}_{2} \cdot 6 \mathrm{H}_{2} \mathrm{O}(10 \cdot 1 \mathrm{~g})$. Sterile $\mathrm{CaCl}_{2}$ solution $(7 \cdot 36 \%, \mathrm{w} / \mathrm{v}$; $20 \mathrm{ml} \mathrm{l}^{-1}$ ) was added immediately before use. Escberichia coli strains were grown in L-broth; for asd auxotrophs, and in screening for asd mutants, the medium was supplemented with DAP.

Manipulation of DNA. Except where selection for $\mathrm{Asd}^{-}$strains was involved, E. coli DH5 $\alpha$ was used for plasmid construction and maintenance; competent cells were prepared and transformed as described by Sambrook et al. (1989). Plasmids from E. coli and S. akiyoshiensis were isolated by the method of Lee \& Rasheed (1990); single-stranded DNA was obtained as described by Sambrook et al. (1989). DNA fragments from plasmids digested with restriction enzymes were separated by electrophoresis in $0.8 \%$ agarose gels; individual fragments were purified with the GeneClean kit (BIO 101). Genomic DNA from $S$. akiyoshiensis was isolated as described by Hopwood et al. (1985); for use in a genomic library it was partially digested with Sau3AI and size-fractionated by centrifugation in a sucrose density gradient (Hopwood et al., 1985).

DNA cloning. Sized 6-15 kb fragments from Sau3AI partial digestion of $S$. akiyoshiensis genomic DNA were ligated behind the lac promoter in pHJL400 (Larson \& Hershberger, 1986) linearized at its Bam $\mathrm{HI}$ site and dephosphorylated with calfintestinal alkaline phosphatase (Promega). The recombinant plasmid library was used to transform competent cells of the $E$. coli asd mutant strain CGSC 6212. Transformed cells were plated on L-broth agar containing ampicillin $\left(100 \mu \mathrm{g} \mathrm{ml}^{-1}\right)$, and examined for prototrophic colonies. Similar transformation and screening methods were used to sub-clone $S$. akiyoshiensis DNA inserts.

Hybridization. Genomic DNA, pJV21 and pJV36 were digested with $P v u I I$. The digests were fractionated in $1 \%(\mathrm{w} / \mathrm{v})$ agarose gels, and DNA was transferred to a nylon membrane (Zeta-Probe, Bio-Rad). The $0.75 \mathrm{~kb}$ Sall fragment of pJV24 was labelled with $\left[\alpha-{ }^{32} \mathrm{P}\right] \mathrm{dCTP}$ by the random priming procedure (Feinberg \& Vogelstein, 1983) for use as the probe. Hybridization was carried out at $65^{\circ} \mathrm{C}$ overnight, after which the membrane was washed at $65^{\circ} \mathrm{C}$ with a solution containing $15 \mathrm{mM}$ sodium chloride, $1.5 \mathrm{~mm}$ sodium citrate and $0.1 \%$ sodium dodecyl sulphate.

DNA sequencing and sequence analysis. The DNA inserts in pJV24 and pJV36 were each subcloned in the phagemids pBluescript II SK(+) and SK(-), allowing both strands to be sequenced; nested deletions were generated by the DNase I method (Sambrook et al., 1989). Single-stranded DNA produced from the phagemids was sequenced by the dideoxynucleotide-mediated chain-termination method (Sanger et al., 1977). Sequenase version 2.0 (US Biochemical) was used for DNA synthesis. The sequence data were analysed with 'DNA strider' (Marck, 1988), and programs (version 7.1) developed by the Genetics Computer Group, University of Wisconsin Biotechnology Center (Devereux et al., 1984). Amino acid sequences deduced from open reading frames (ORFs) were 
Table 1. Bacteria, plasmids and phage used

\begin{tabular}{|c|c|c|}
\hline & Genotype/phenotype & Source/reference \\
\hline \multicolumn{3}{|l|}{ Strains } \\
\hline $\begin{array}{l}\text { Streptomyces akiyoshiensis } \\
\text { ATCC } 1348\end{array}$ & Wild-type & American Type Culture Collection \\
\hline \multicolumn{3}{|l|}{ Escherichia coli } \\
\hline CGSC 5074 & $\begin{array}{l}\mathrm{F}^{-} \text {thr A1101 supE44 } \lambda^{-} \text {rpsL9 malT1 }\left(\lambda^{\mathrm{R}}\right) \times y l-7 \text { mtl-2 } \\
\text { ilv A296 metL1000 arg-1000 thi-1 lysC1001 }\end{array}$ & E. coli Genetic Stock Center \\
\hline CGSC 6212 & $\begin{array}{l}\mathrm{F}^{-} \phi 80 \mathrm{~d} l a c Z \Delta(\operatorname{lac} Z Y A-\arg F) 4169 \text { supE } 44 \lambda^{-} \operatorname{gyr} A \operatorname{rec} A 1 \\
\quad r e l A 1 \text { end } A 1 \Delta \text { asd } 4[\text { zbf-2::Tn10] bsdR } 17\end{array}$ & $\begin{array}{l}\text { R. Curtiss III, Biology Department, } \\
\text { Washington University }\end{array}$ \\
\hline DH5 $\alpha$ & $\begin{array}{l}\mathrm{F}^{-} \phi 80 \mathrm{~d} l a c \Delta \mathrm{M} 15 \Delta(\operatorname{lac} Z Y A-\arg F) U 169 \operatorname{supE} 44 \lambda^{-} \text {thi-1 } \\
\operatorname{gyr} A \operatorname{rec} A 1 \operatorname{rel} A 1 \text { end } A 1 \text { bsdR } 17\end{array}$ & Sambrook et al. (1989) \\
\hline \multicolumn{3}{|l|}{ Plasmids and phage } \\
\hline $\mathrm{pHJL} 400$ & $\mathrm{Amp}^{\mathrm{r}}$ lac $Z^{\prime} t s r ;$ bifunctional & Larson \& Hershberger (1986) \\
\hline pJV21 & Amp $^{r}$ lac $Z^{\prime}$ asd $d^{+} t s r$; bifunctional & This study \\
\hline pJV24, pJV36 & Amp $^{r}$ lac $Z^{\prime}$ asd; bifunctional & This study \\
\hline pJV30 & Amp ${ }^{r}$; bifunctional & This study \\
\hline p'TZ18R, pTZ19R & $A m p^{r} l a c Z^{\prime}$ & Mead \& Kemper (1988) \\
\hline pJV31, pJV32 & Amp ${ }^{r}$ lac $Z^{\prime}$ asd $d^{+}$ & This study \\
\hline pBluescript II SK(+) and SK(-) & $A m p^{r} l a c Z^{\prime}$ & Stratagene \\
\hline pJV25-29, pJV34-35 & $A_{m p}^{r}$ & This study \\
\hline VCSM13 & $\operatorname{Kan}^{r}$ & Stratagene \\
\hline
\end{tabular}

compared with sequences in the GenBank database using BLAST (Altschul et al., 1990). Amino acid sequences were aligned using CLUSTAL software (Higgins \& Sharp, 1988).

\section{RESULTS}

\section{Cloning of asd from $S$. akiyoshiensis}

A library of $S$. akiyoshiensis DNA fragments in the Streptomyces-E. coli shuttle vector $\mathrm{pHJL400}$ (Larson \& Hershberger, 1986) was used to transform the E. coli asd mutant strain CGSC 6212. Screening approximately 39000 transformants for prototrophy yielded one $\mathrm{Asd}^{+}$ colony, from which we recovered a $17 \mathrm{~kb}$ plasmid (pJV21; Fig. 2) that conferred the Asd ${ }^{+}$phenotype. To locate the asd gene within the $11.2 \mathrm{~kb}$ insert, pJV21 was partially digested with $S a l I$, and the fragments were ligated with the $4.9 \mathrm{~kb}$ vector fragment generated when pH JL400 was digested with Sall. Transformation of $E$. coli CGSC 6212 with the ligation mixture, selection of $\mathrm{Asd}^{+}$transformants, and screening of these for the smallest plasmid present gave pJV24. This plasmid contained a $2.2 \mathrm{~kb}$ insert but lacked a $0.9 \mathrm{~kb}$ region of pHJL400 containing lac $Z^{\prime}$ and $t s r$ sequences that had been removed during the digestion with SalI (see Fig. 2).

Approximately $0.2 \mathrm{~kb}$ of DNA adjacent to the lac promoter was excised from the pJV24 insert by digesting the plasmid with a Bam HI/KpnI mixture and subcloning the remainder of the insert in pHJL400 similarly digested with Bam HI and KpnI. The plasmid (pJV30) obtained by transforming E. coli CGSC 6212 in the presence of DAP failed to complement the asd mutation in this host when DAP was omitted from the medium. Since the KpnI site, like the Sall site, is located within the tsr sequence of
pHJL400, and thus should not affect asd expression, the results positioned asd near the end of the insert adjoining the vector promoter in pJV24. To obtain a fragment containing asd with a larger flanking region of $S$. akiyoshiensis DNA at this end, pJV24 was digested with HindIII and Bam HI; the $6.9 \mathrm{~kb}$ fragment in the digest was ligated to the $1 \cdot 2 \mathrm{~kb}$ fragment of insert DNA recovered by gel electrophoresis from a HindIII/Bam HI double digest of pJV21 (see Fig. 2); transformation of E. coli CGSC 6212 and selection for asd yielded pJV36, containing a $3.3 \mathrm{~kb}$ insert.

\section{Sequencing and analysis of the DNA cloned in pJV36}

The $S$. akiyoshiensis DNA insert cloned in pJV24 was excised as a mixture of 0.75 and $1.4 \mathrm{~kb}$ fragments by digesting the plasmid with Sall. The fragments were separated by gel electrophoresis, and each was cloned in the Sall site of pBluescript II SK $(+)$ to give pJV25 and pJV27, respectively; the single-stranded DNA generated from them was sequenced. To obtain the opposite strands, the inserts in pJV25 and pJV27 were excised with HindIII/KpnI, and ligated to similarly digested pBluescript II SK(-), giving pJV26 and pJV28, respectively. The sequence at the junction of the 0.75 and $1.4 \mathrm{~kb}$ fragments was confirmed by subcloning the $0.75 \mathrm{~kb}$ BamHI-Sst fragment of pJV24 in Bam HI/SstI-digested pBluescript II SK $(+)$, and sequencing single-strand DNA obtained from the resulting phagemid pJV29. The region of pJV36 not already sequenced in pJV24 was subcloned as a $1.2 \mathrm{~kb} H$ indIII-Bam HI fragment in HindIII/BamHIdigested pBluescript II SK $(+)$ and pBluescript II SK $(-)$ to give pJV34 and pJV35, respectively. ORFs in the nucleotide sequence were detected with the 


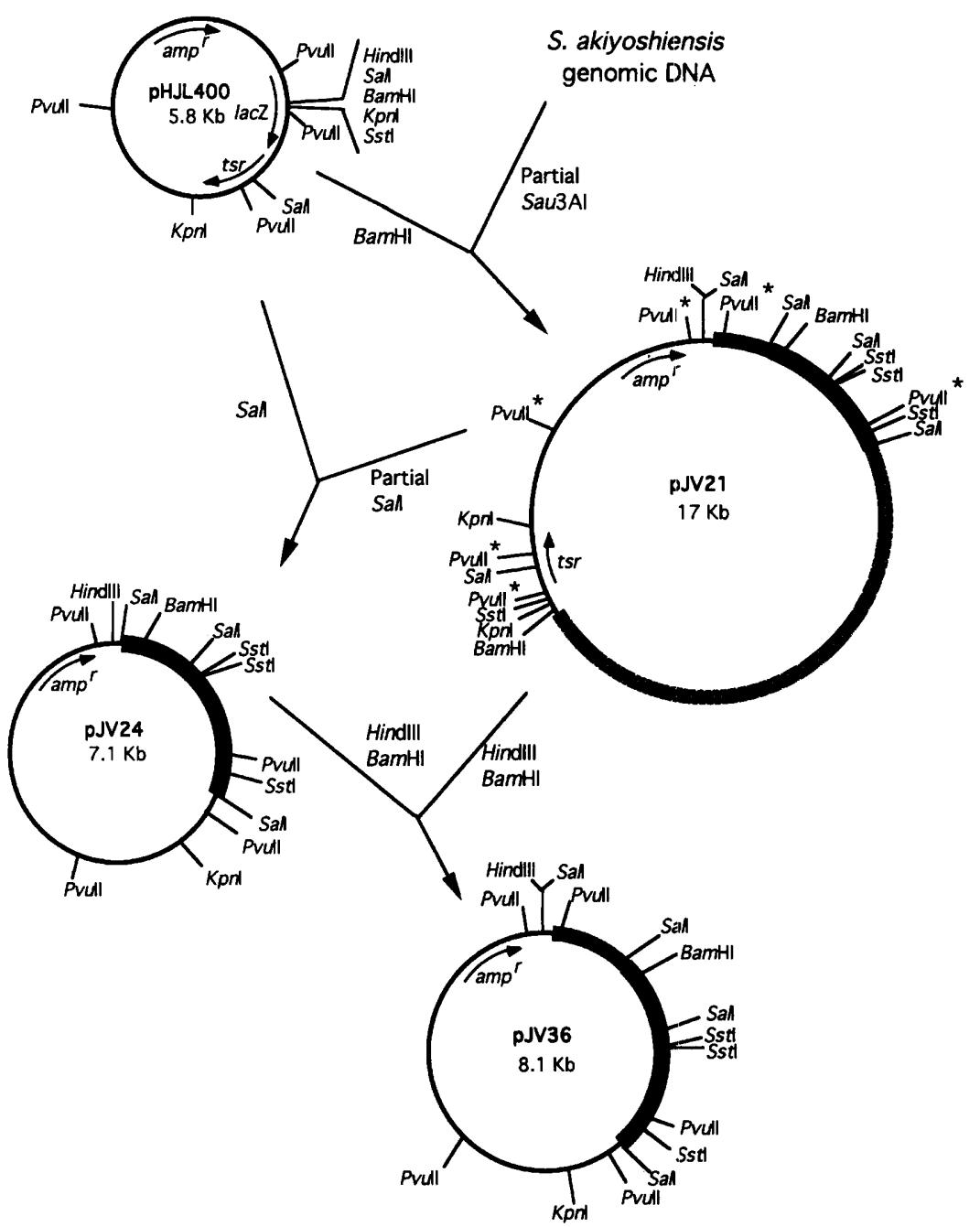

Fig. 2. Construction of recombinant plasmids. A partial Sau3Al digest of $S$. akiyoshiensis DNA was ligated with BamHIlinearized pHJL400 to give pJV21. Partial Sall digestion of pJV21 and ligation with a Sall digest of pHJL400 yielded pJV24. To construct pJV36, the $1.2 \mathrm{~kb}$ insert fragment obtained by digesting pJV21 with HindIII and BamHI was ligated to pJV24, from which a $0.2 \mathrm{~kb}$ fragment had been removed by HindlII/BamHI digestion. All plasmids were isolated from transformants of $E$. coli CGSC 6212 selected for prototrophy. Asterisks identify restriction enzymes for which sites additional to those shown are present in a plasmid.

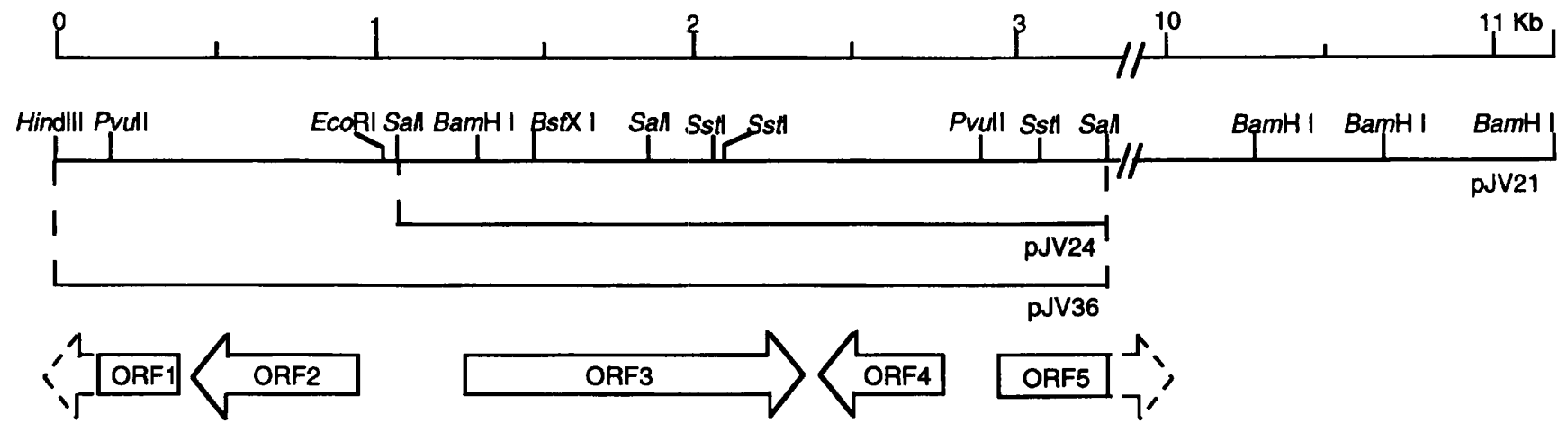

Fig. 3. Map of selected restriction sites in the S. akiyoshiensis DNA inserts of pJV21, pJV24 and pJV36. For Sall, only sites present in all three plasmids are included. For Pvull and BstXI, only sites present in both pJV21 and pJV36 are included; HindlII is in the vector polylinker. ORFs and their orientation are shown as boxed arrows; incomplete ORF segments are shown by broken outlines.

CODONPREFERENCE program (Devereux et al. 1984) using the table for frequency of codon usage in streptomycetes compiled by Wright \& Bibb (1992). Two incomplete ORFs (1 and 5) and three complete ORFs were present in the pJV36 insert (Fig. 3).

\section{Sequence of asd from S. akiyoshiensis}

A comparison of amino acid sequences in the GenBank database with sequences deduced from ORFs 1-5 in the cloned $S$. akiyoshiensis DNA showed strong similarities 


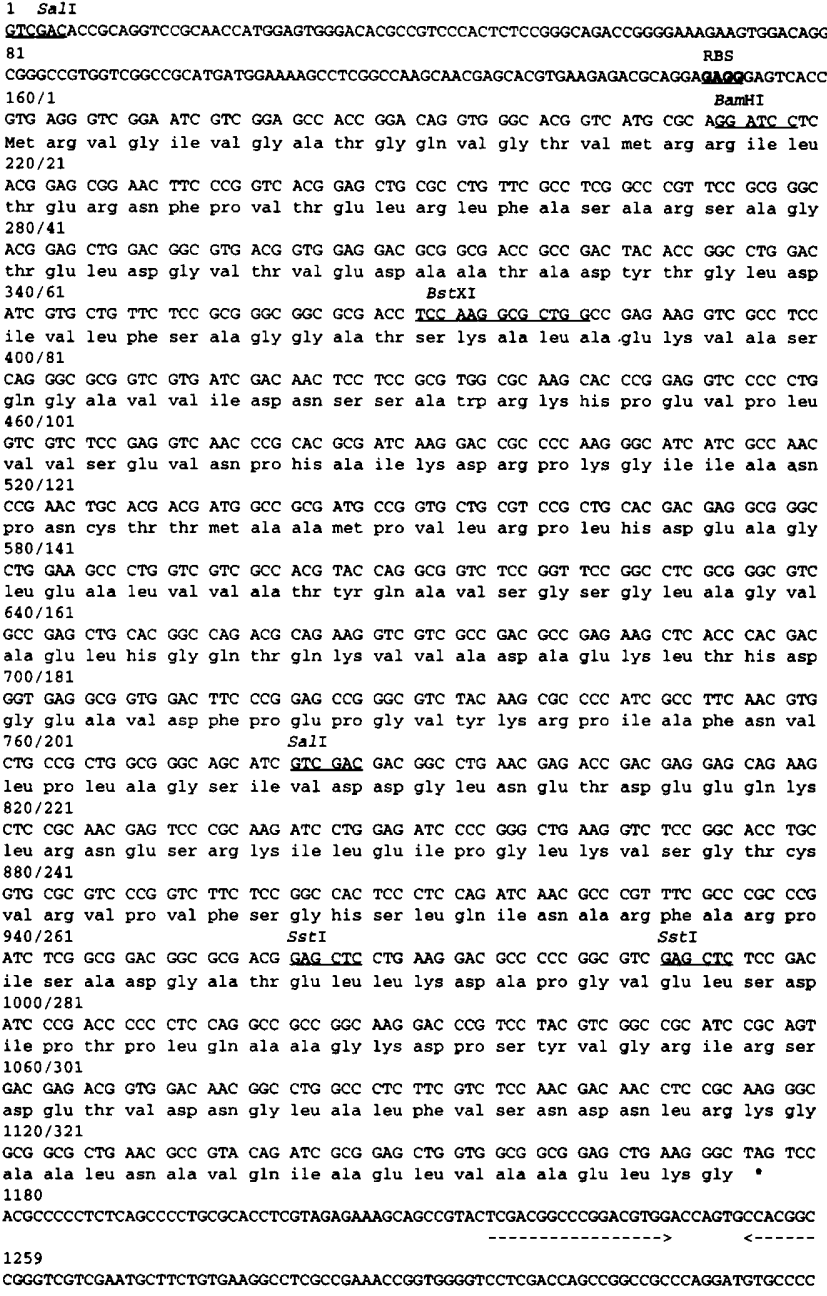
CGGGTCGTCGAATG

Fig. 4. Nucleotide sequence of the $1337 \mathrm{bp}$ lefthand segment of pJV24 containing ORF3 (see Fig. 3); the deduced amino acid sequence for ORF3 is shown. Restriction sites are underlined; the putative ribosome-binding site (RBS) for ORF3 is underlined and in boldface. A downstream inverted repeat is marked with broken arrows.

between the ORF3 sequence and Asd from a variety of micro-organisms. Fig. 4 shows the nucleotide and deduced amino acid sequences of the region in pJV24 containing ORF3. In a CLUSTAL alignment with the ORF3 polypeptide (Fig. 5), the amino acid sequences of Asd from Gram-positive bacteria showed the following frequency of identical amino acids: Mycobacterium smegmatis (Cirillo et al., 1994), $66 \%$ over 200 amino acids; Corynebacterium glutamicum (Kalinowski et al., 1990), 60\% over 271 amino acids; Bacillus subtilis (Chen et al., 1993), $48 \%$ over 60 amino acids; Streptococcus mutans (Cardineau \& Curtiss, 1987), $43 \%$ over 62 amino acids. The sequence identity was lower (38\% over 42 amino acids) with Asd from E. coli (Biellmann et al., 1980), and also (24\% over 62 amino acids) with Asd from Saccharomyces cerevisiae (Thomas \& Surdin-Kerjan, 1989).

The mean $\mathrm{G}+\mathrm{C}$ content in ORF3 was $70.1 \mathrm{~mol} \%$, with $69 \cdot 1,44.7$ and $96.5 \mathrm{~mol} \%$ in the first, second and third positions, respectively, of the codons; the values are similar to those reported for streptomycete ORFs (Seno \& Baltz, 1989). ORF3 has a potential start codon (GTG) at nt $160-162$, which is preceded at nt $148-151$ by a plausible ribosome-binding site [GAGG; $\Delta G$ $-9.4 \mathrm{kcal} \mathrm{mol}^{-1}\left(-39 \cdot 0 \mathrm{~kJ} \mathrm{~mol}^{-1}\right)$; Tinoco et al., 1973]. A comparison of the region upstream of the translational start codon with the sequences of promoter recognition sites in streptomycetes (Strohl, 1992) did not identify any sequences corresponding to E. coli $\sigma^{70}$-like -10 and -35 hexamers. The translational stop codon (TAG) is at nt 1174-1176. Beginning $45 \mathrm{nt}$ downstream of this, sequences at nt 1227-1244 and 1252-1269 were identified as an imperfect inverted repeat by the STEMLOOP program (Devereux et al., 1984); the binding strength for the corresponding mRNA, calculated by MFOLD, is $-29 \cdot 2 \mathrm{kcal} \mathrm{mol}^{-1}\left(-122 \cdot 2 \mathrm{~kJ} \mathrm{~mol}^{-1}\right)$, suggesting that the inverted repeat forms a transcriptional terminator (Adhya \& Gottesman, 1978).

The sequence analysis indicated that ORF3 codes for a polypeptide of $M_{\mathrm{r}} 35484$ containing 338 amino acids. The conclusion from comparisons with database sequences that it constitutes the gene for Asd in S. akiyoshiensis is supported by the failure of pJV30 to complement the asd mutation in E. coli CGSC 6212. Sequence analysis indicates that the BamHI-KpnI segment of pJV24 subcloned in this plasmid lacks the first 18 codons of ORF3 and an upstream region that includes the putative ribosome-binding site.

\section{Expression of asd from the lac promoter}

The absence of a recognizable promoter sequence upstream of asd in the DNA fragment cloned from $S$. akiyoshiensis suggested that the gene was expressed in $E$. coli from the lac promoter of the vector. This was investigated by inserting DNA fragments containing asd in opposite orientations into an E. coli vector. The $S$. akiyoshiensis DNA inserts in pJV21 and pJV24 were excised by double digestion with HindIII/KpnI, and recloned downstream of the lac promoter in HindIII/ KpnI-digested pTZ18R and pTZ19R; these vectors differ in the opposite orientation of their multiple cloning regions. Only pJV31 and pJV32, in which the inserts from pJV21 and pJV24, respectively, were cloned in pTZ19R, complemented the asd mutation in E. coli CGSC 6212. Since the orientation of asd to the lac promoter in these plasmids was the same as in pJV21 and pJV24, the results indicate that in the initial shotgun cloning, asd from $S$. akiyoshiensis was expressed from the lac promoter of $\mathrm{pHJL} 400$.

\section{Regions adjacent to asd}

The amino acid sequences deduced from ORF4 and the incomplete ORF1 did not show significant similarity to sequences in the GenBank database. The amino acid sequence deduced from ORF2 showed a marked similarity to sigma factors (Lonetto et al., 1994); this is being investigated with $M$. Buttner and M. Paget at the John 
s. a. M-R---VGIVGATGQVGTVMRR-ILTERNFPVTELRLF-ASARSAGTE----ID----GVTVEDAATA----DYTGL- -DIVLFSAGGATSKALAEKV M. s. MVN---IGVVGATGQGRQVMRN-LLEQRNFPATSVRFF-ASPRSEGKK----LTFRGQEIEVENAETA-----DPSGL---DIALFSAGATMSRVQAPRF

c. g. MTT---IAVVGATGQVGQVMRT-LLEERNFPADTVRFF-ASPRSAGRK----IEFRGTEIEVEDITQA-----TEESLKDIDVALFSAGGTASKQYAPLF

B. s. MGRGLHVAVVGATGAVGQQMLK-TLEDRNFEMDTLTLL-SSKRSAGTK----VTFKGQELTVQEASP--------ESFEGVNIALF SAGGSVSQALAPEA

s. m. MG--YTVAIVGATGAVGTRMIQ-QLEQSTLPVDKVRLL-SSSRSAGKV----LQYKDQDVTVELTTK---.----DSFEAVDIALFSAGGSVSAKFAPYA

s. c. MAGKKIAGVLGATGSVGQRFIL-LLANH--PHFELKVLGASSRSAGKKYVDAVNWKQTDLLPESATDIIVSECKSEFFKECDIVFSGLDADYAGAIEKEF

E. c. MKN---VGFIGWRGMVGVLMQRMVEERDFDAIRPVFFST SQLGQA----APSFGGTTGTLQDAFDL------EALKALDIIVTCQGGDYTNEIYPKL

S. a. ASQGAVV--IDNSSAWRKHPEVPLVVSEVN------PHAIKDRPKG-------IIANPNCTTMAAMPVLRPLHDEAG-LEALVVATYQAVSGSGLAGVA

M. s. AEAGVIV--VDNSSAFRKDPDVPLVVSEVN---FDRDVRGKKLAKG-------IIANPNCTTMAAMPVLKPLHEEAG-LQRLIVSSYQAVSGSGIAGVE

C. g. AAAGATV--VDNSSAWRKDDEVPLIVSEVN-----PSDKDSLVKG------IIANPNCTTMAAMPVLKPLHDAAG-LVKLHVSSYQAVSGSGLAGVE

B. S. VKRGAIV--IDNTSAFRMDENTPLVVPEVN------EADLHEHNG-.....-IIANPNCSTIQMVAALEPIRKAYG-LNKVIVSTYQAVSGAGNEAVK

s. m. VKAGAVV--VDNTSHFRQNPDVPLVVPEVN------AYAMDAHNG-------IIACPNCSTIQMMVALEPIRQKWG-LSRVIVSTYQAVSGAGQSAIN

s. c. MEAGIAI--VSNAKNYRREQDVPLIVPVVNPEHLDIVAQKLDTAKAQGKPRPGFIICISNCSTAGLVAPLKPLIEKFGPIDALTTTTLQAISGAGFSPGV

E. c. RESGWQGYWIDAASSLRMKDDAIIILDPVNQDVIT-.--.--DGLNNGIRTFV--GGNCTVSLMLMSLGGLFAN-DLVDWVSVATYQAASGGGARHMR

S. a. ELHGQTQKVVADAEKLTHDGEAVDFP---------EPGVYKRPIAFNVLPLAGS IVDDGLNETDEEQKLRNESRKILEIPGL-KVSGTCVRVPVF

M. $s$. ELAGQARPVIDGVEQLVHDGSALQYP--_-_-_-_APNKYVAPIAFNIVPLAGNYVDDGSGETDEDQKLRNESRKILGIPEL-LVSGTCVRVPVF

c. g. TLAKQVAAVGDHNVEFVHDGQAADAG--------DVGPYVSPIAYNVLPFAGNLVDDGTFETDEEQKLRNESRKILGLPDL-KVSGTCVRVPVF

B. $s$. ELYSQTQAILNKE----EIEPEIMPV---------KGDKKHYQIAFNAIPQIDKFQDNGY--TFEEMKMINETKKIMHMPDL-QVAATCVRLPIQ

s. $m$. ETVREIKEVVNDGVDPKAVHADIFPS---------GGDKKHYPIAFNALAQIDVFTDNDY--TYEEMKMTNETKKIMEEPEL-PVSAHCVRVPIL

s. c. P----GIDILDNI IPYIGGEED----- -

E. c. ELLTQMGHLYGHVADELATPSSAILDIERKVTTLTRSGEL FVDNFGVPLAGSLIPWIDKQLDNG--QSREEWKGQAETNKILNTSSVIPVDGLCVRVGAL

s. a. SGHSLQINARF-ARPI-SADGATELLKD--------APGVELSD------IPTPLQAAGKDPSY---VGRIRSDETVDN--GL-ALFVSNDNLRKGA

$M$. s. SGHSLSINAEF-SQPI-SVERTKELLSA---------AAGVKLVD------VPTPLAAAGIDDCL---VGRIRQDPGVPDGRGL-ALFVSGDNLRKGA

c. g. TGHTLTIHAEF-DKAI-TVDQAQEILGA---------ASGVKLVD-----VPTPLAAAGIDESL---VGRIRQDSTVDDNRGL-VLVVSGDNLRKGA

B. s. TGHSESVYIEI -DRDDATVEDIKNLLKE---------APGVTLQDDPSQQLYPMPADAVGKNDVF---VGRIRKD--LDRANGF-HLWVVSDNLLKGA

s. $m$. FSHSEAVYIET--KDVAPIEEVKAAIAA--_-_-_--FPGAVLEDDIKHQIYPQAANAVGSRT-F---VGRIRKD--LDIENGI-HMWVVSDNLLKGA

s. c. DGHTECISLRFKNRPAPSVEQVKTCLKEYVCDAYKLGCHSAPKQTIHVLEQPDRPQPRLDRNRDSGYGVSVGRIREDPLLD----F-KMVVLSHNTIIGA

E. c. RCHSQAFTIKLKKD--VSIPTVEELLAA------HNPWAKVVPN-DREITMRELTPAAVTGTLTTPVGRLRK---LNMGPEFLSAFTVGDQLLWGA $\star$.

S. a. ALNAVQIAELV-------AAELK---G

M. S. ALNTIQIAELL------ AADL-- - -

C. g. ALNTIQIAELL-------VK- - - -

B. S. AWNSVQIAESLK-...-..--KLNLV

S. $m$. AWNSIITANRLHERGLVRSTSELKFELK

S. c. AGSGVLIAEILLARNLI-_-....-

E. C. A------EPL--RRMLR------QLA

* $\quad$.

Fig. 5. CLUSTAL alignment (Higgins \& Sharp, 1988) of deduced amino acid sequences for asd cloned from bacteria. Identical and similar amino acids are indicated below the alignment by asterisks and dots, respectively. S. a., Streptomyces akiyoshiensis; M. s., Mycobacterium smegmatis; C. g., Corynebacterium glutamicum; B. s., Bacillus subtilis; S. m., Streptococcus mutans; S. c., Saccharomyces cerevisiae; E. c., Escherichia coli.

Innes Institute, Norwich, UK. The deduced amino acid sequence for the incomplete ORF5 showed strong similarity (85\% identity over 119 amino acids) to the Nterminal region of aminopeptidase $\mathrm{N}$ from Streptomyces lividans (Butler et al., 1994).

\section{Southern analysis of cloned and chromosomal DNA}

S. akiyoshiensis genomic DNA and the plasmids pJV21 and pJV36 were digested with PvuII and probed by Southern hybridization with an $\alpha^{3}{ }^{32}$ P-labelled $0.75 \mathrm{~kb}$ SalI-SalI fragment from pJV24. The probe detected a single $2.8 \mathrm{~kb}$ fragment in all three digests, indicating that the cloned PvuII fragment represented the true chromosomal sequence.

\section{Transformation of an ask mutant of $E$. coli}

pJV21 and pJV24 were used to transform E. coli CGSC 5074 , an auxotrophic strain carrying mutations in each of the three genes encoding Ask isozymes (Theze et al., 1974). None of the transformants was prototrophic. Since complementation of any of the defective isozyme genes would have supported growth, the result indicated that ask was either absent from the plasmids or, if present, was not expressed.

\section{DISCUSSION}

Of the possible start codons for ORF3, the GTG at nt 160-162 gives an $\mathrm{N}$-terminal amino acid sequence corresponding closely to those deduced for asd from other 
Gram-positive organisms. In addition, this location offers a plausible ribosome-binding site appropriately spaced from the translational start codon (Strohl, 1992). Expression of the cloned S. akiyoshiensis asd in E. coli from the lac promoter of the vector is consistent with the apparent lack of an E. coli-like promoter in the region upstream of ORF3. It was also noted (data not shown) that expression in E. coli increased with addition of IPTG to the culture medium, and that expression was higher from asd cloned in pJV24 than from the gene in pJV21, where it is more distant from the lac promoter.

The deduced amino acid sequence of ORF3 shows significant similarity to the Asds in low \% G + C Grampositive bacteria (Bacillus and Streptococcus), as well as to those in E. coli and Saccharomyces cerevisiae. However, it is most similar to the Asds of mycobacteria and corynebacteria, which like streptomycetes are high \% $\mathrm{G}+\mathrm{C}$ Gram-positive bacteria. To date, no wellcharacterized mutant blocked in a core reaction of the aspartate pathway in streptomycetes has been reported, and thus the loci for these genes have not been mapped. The marked similarity in deduced amino acid sequence between ORF3 of S. akiyoshiensis and the Asd sequences of other high \% G + C Gram-positive bacteria raised the possibility that the aspartate pathway genes might be similarly organized. In mycobacteria, corynebacteria and bacilli, asd is clustered in an operon with ask (Kalinowski et al., 1990; Chen et al., 1993; Cirillo et al., 1994). However, no ask-like sequence was detected by analysis of the DNA cloned from regions immediately upstream or downstream of asd in $S$. akiyoshiensis. The absence of ask was consistent with the failure of either pJV21 or pJV24 to complement an E. coli ask mutant, but this failure might also be attributed to lack of expression (Seno \& Baltz, 1989). Since a probe excised from the asd gene hybridized with $2.8 \mathrm{~kb}$ PvuII fragments in pJV21, pJV36 and the $S$. akiyoshiensis chromosome, the sequenced region of the cloned fragments had probably not undergone deletion or rearrangement, and represents the native sequence. A comparison of streptomycete genomes has shown extensive structural conservation of the genes for primary metabolism (Stuttard, 1988); thus the difference in organization between ask and asd in S. akiyoshiensis and in other Gram-positive bacteria examined is likely to apply to streptomycetes generally.

In the lysine branch of the aspartate pathway in streptomycetes, DAP is not only a metabolic intermediate but also represents an essential cell wall component. Most culture media lack DAP; thus in mutants where its endogenous synthesis is blocked, plasmids carrying a gene complementing the mutation are maintained as a condition for survival. The use of asd mutants in such plasmid maintenance systems has been demonstrated in a Salmonella vaccine strain (Nakayama et al., 1988). Since streptomycetes are potentially useful organisms for producing proteins with recombinant vectors (Takaguchi $e t$ al., 1989; Baltz, 1990; Bender et al., 1990), we attempted to develop a similar system ensuring vector maintenance in streptomycete hosts without antibiotic selection. Chemical mutagenesis and screening of $S$. akiyoshiensis spores failed to yield a specific asd mutation. S. akiyoshiensis could be efficiently transformed with pHJL400, and efforts were then directed towards replacement of asd with a cloned and disrupted vector copy of the gene. However, we were unable to select transformants with an $\mathrm{Asd}^{-}$ phenotype. Attempts in other laboratories to isolate asd mutants by chemical mutagenesis of corynebacteria (Yeh et al., 1988), and by gene disruption of mycobacteria (Cirillo et al., 1991) and bacilli (Chen et al., 1993), have also been unsuccessful, and Chen et al. (1993) suggested that absence of an uptake system for DAP in these bacteria makes asd a lethal mutation. We have observed that $S$. akiyoshiensis shows little growth with DAP as a sole nitrogen source, but normal growth with lysine (data not shown). Thus here as well, inability to transport DAP may account for the absence of asd mutants.

\section{ACKNOWLEDGEMENTS}

We are grateful to Dr R. Curtis III for the culture of E. coli CGSC 6212, and to Dr B. J. Bachmann for E. coli CGSC 5074. This research was supported by the Natural Sciences and Engineering Research Council of Canada, and by the World University Service of Canada.

\section{REFERENCES}

Adhya, S. \& Gottesman, M. (1978). Control of transcription termination. Annu Rev Biochem 47, 967-996.

Altschul, S. F., Gish, W., Miller, W., Myers, E. W. \& Lipman, D. J. (1990). Basic local alignment search tool. J Mol Biol 215, 403-410.

Baltz, R. H. (1990). Gene expression using streptomycetes. Curr Opin Biotechnol 1, 12-20.

Bender, E., Koller, K.-P. \& Engels, J. W. (1990). Secretory synthesis of human interleukin-2 by Streptomyces lividans. Gene 86, 227-232.

Biellmann, J.-F., Eid, P., Hirth, C. \& Jornavall, H. (1980). Aspartate$\beta$-semialdehyde dehydrogenase from Escherichia coli. Eur $J$ Biochem 104, 59-64.

Butler, M. J., Aphale, J. S., Binnie, C., DiZonno, M. A., Krygsman, P., Soltes, G. A., Waiczyk, E. \& Malek, L. T. (1994). A gene encoding an aminopeptidase $\mathrm{N}$ from S. lividans 66. Gene 141, 115-119.

Cardineau, G. A. \& Curtiss, R., III (1987). Nucleotide sequence of the asd gene of Streptococcus mutans. J Biol Chem 262, 3344-3553.

Chen, N.-Y., Jiang, S.-Q., Klein, D. A. \& Paulus, H. (1993). Organization and nucleotide sequence of the Bacillus subtilis diaminopimelate operon, a cluster of genes encoding the first three enzymes of diaminopimelate synthesis and dipicolinate synthase. $J$ Biol Chem 268, 9448-9465.

Cirillo, J. D., Barletta, R. G., Bloom, B. R. \& Jacobs, W. R., Jr (1991). A novel transposon for mycobacteria : isolation and characterization of IS1096. J Bacteriol 173, 7772-7780.

Cirillo, J. D., Weisbrod, T. R., Pascopella, L., Bloom, B. R. \& Jacobs, W. R., Jr (1994). Isolation and characterization of the aspartokinase and aspartate semialdehyde dehydrogenase operon from mycobacteria. Mol Microbiol 11, 629-639.

Cohen, G. N., Stanier, R. Y. \& LeBras, G. (1969). Regulation of the biosynthesis of amino acids of the aspartate family in coliform bacteria and pseudomonads. J Bacteriol 99, 791-801.

Cremer, J., Treptow, C., Eggeling, L. \& Sahm, H. (1988). Regulation of enzymes of lysine biosynthesis in Corynebacterium glutamicum. $J$ Gen Microbiol 134, 3221-3229. 
Devereux, J., Haeberli, P. \& Smithies, O. (1984). A comprehensive set of sequence analysis programs for the VAX. Nucleic Acids Res 12, 387-395.

Feinberg, A. P. \& Vogelstein, B. (1983). A technique for radiolabeling restriction endonuclease fragments to high specific activity. Anal Biochem 132, 6-13.

Higgins, D. G. \& Sharp, P. M. (1988). Clustal: a package for performing multiple sequence alignments on a microcomputer. Gene 73, 237-244.

Hopwood, D. A., Bibb, M. J., Chater, K. F., Kieser, T., Bruton, C. J., Kieser, H. M., Lydiate, D. J., Smith, C. P., Ward, J. M. \& Schrempf, H. (1985). Genetic Manipulation of Streptomyces: a Laboratory Manual. Norwich: John Innes Foundation.

Kalinowski, J., Bachmann, B., Thierbach, G. \& Puhler, A. (1990). Aspartokinase genes $l y s C \alpha$ and $l y s C \beta$ overlap and are adjacent to the aspartate $\beta$-semialdehyde dehydrogenase gene asd in Corynebacterium glutamicum. Mol \& Gen Genet 224, 317-324.

Kanazawa, K., Tsuchiya, K. \& Araki, T. (1960). A new antituberculosis amino acid (5-hydroxy-4-oxo-L-norvaline. $A m$ Rev Resp Dis 81, 924.

Larson, J. L. \& Hershberger, C. L. (1986). The minimum replicon of a streptomycete plasmid produces an ultrahigh level of plasmid DNA. Plasmid 15, 199-209.

Le, Y. (1994). Biosynthesis of 5-bydroxy-4-oxonorvaline and aspartate family amino acids in Streptomyces akiyoshiensis. PhD thesis, Dalhousie University, Halifax, Canada.

Lee, S.-Y. \& Rasheed, S. (1990). A simple procedure for maximum yield of high quality plasmid DNA. BioTechniques 9, 676-679.

Lonetto, M., Brown, K. L., Rudd, K. \& Buttner, M. J. (1994). Analysis of the Streptomyces coelicolor sigE gene reveals the existence of a subfamily of eubacterial RNA polymerase sigma factors involved in the regulation of extracytoplasmic functions. Proc Natl Acad Sci USA 91, 7573-7577.

Madduri, K., Stuttard, C. \& Vining, L. C. (1989). Lysine catabolism in Streptomyces spp. is primarily through cadaverine: $\beta$-lactam producers also make $\alpha$-aminoadipate. J Bacteriol 171, 299-302.

Marck, C. (1988). 'DNA Strider': a 'C' program for the fast analysis of DNA and protein sequences on the Apple Macintosh family of computers. Nucleic Acids Res 16, 1829-1836.

Mead, D. A. \& Kemper, B. (1988). Chimeric single-strand DNA phage-plasmid cloning vectors. In Vectors, pp. 85-102. Edited by R. L. Rodriguez \& D. T. Denhardt. Toronto: Butterworths.

Mendelovitz, S. \& Aharonowitz, Y. (1982). Regulation of cephamycin C synthesis, aspartokinase, dihydrodipicolinic acid synthetase and homoserine dehydrogenase by aspartic acid family amino acids in Streptomyces clavuligerus. Antimicrob Agents Chemother 21, 74-84.

Nakayama, K., Kelly, S. \& Curtiss, R., III (1988). Construction of an $\mathrm{Asd}^{+}$expression vector: stable maintenance and high level expression of cloned genes in a Salmonella vaccine strain. Bio/Technology 6, 693-697.

Sambrook, J., Fritsch, E. F. \& Maniatis, T. (1989). Molecular Cloning: a Laboratory Manual, 2nd edn. Cold Spring Harbor, NY: Cold Spring Harbour Laboratory.

Sanger, F., Nicklen, S. \& Coulson, A. R. (1977). DNA sequencing with chain-terminating inhibitors. Proc Natl Acad Sci USA 74, 5463-5467.
Seno, E. T. \& Baltz, R. H. (1989). Structural organization of antibiotic biosynthesis and resistance genes in actinomyces. In Regulation of Secondary Metabolites in Actinomycetes, pp. 1-48. Edited by S. Shapiro. Boca Raton, FL: CRC Press.

Shiio, I. \& Miyajima, R. (1969). Concerted inhibition and its reversal by end-products of aspartate kinase in Brevibacterium flavum. $J$ Biochem 65, 849-859.

Strohl, W. R. (1992). Compilation and analysis of DNA sequences associated with apparent streptomycete promoters. Nucleic Acids Res 20, 961-974.

Stuttard, C. (1982). Temperate phages of Streptomyces venezuelae: lysogeny and host specificity shown by phages SV1 and SV2.J Gen Microbiol 128, 115-121.

Stuttard, C. (1988). Transduction and genome structure in Streptomyces. Dev Ind Microbiol 29, 69-76.

Takaguchi, S., Kumagai, I., Nakayama, J., Suzuki, A. \& Miura, K. (1989). Efficient extracellular expression of a foreign protein in Streptomyces using secretory protease inhibitor (SSI) gene fusion. Bio/Technology 7, 1063-1066.

Theze, J., Margarita, D., Cohen, G. N., Borne, F. \& Patte, J. C. (1974). Mapping of the structural genes of three aspartokinases and of the two homoserine dehydrogenases of Escherichia coli K12.J Bacteriol 117, 133-143.

Thomas, D. \& Surdin-Kerjan, Y. (1989). Structure of the HOM2 gene of Saccharomyces cerevisiae and regulation of its expression. Mol $\mathcal{E}$ Gen Genet 217, 149-154.

Tinoco, I., Jr, Borer, P. N., Dengler, B., Levine, M. D., Uhlenbeck, O. C., Crothers, D. M. \& Gralla, J. (1973). Improved estimation of secondary structure in ribonucleic acids. Nature New Biol 246, 40-41.

Vining, L. C., Shapiro, S., Madduri, K. \& Stuttard, C. (1990). Biosynthesis and control of $\beta$-lactam antibiotics: the early steps in the 'classical' tripeptide pathway. Biotecbnol Adv 8, 159-183.

White, R. L., DeMarco, A. C. \& Smith, K. C. (1988). Biosynthesis of the unusual amino acid 5-hydroxy-4-oxonorvaline. J Am Chem Soc 110, 8228-8229.

Whitney, J. G., Brannon, D. R., Mabe, J. A. \& Wicker, K. J. (1972). Incorporation of labeled precursors into A16886B, a novel $\beta$-lactam antibiotic produced by Streptomyces clavuligerus. Antimicrob Agents Chemother 1, 247-251.

Wright, F. \& Bibb M. J. (1992). Codon usage in the $G+C$ rich Streptomyces genome. Gene 113, 55-65.

Yamaguchi, M., Yamaki, H., Shinoda, T., Yoshitaka, T., Suzuki, H., Nishimura, T. \& Yamaguchi, H. (1990). The mode of antifungal action of $(S)$-2-amino-4-oxo-5-hydroxypentanoic acid RI-331. $J$ Antibiot 43, 411-416.

Yeh, P., Sicard, A. M. \& Sinskey, A. J. (1988). General organization of the genes specifically involved in the diaminopimelate-lysine biosynthetic pathway of Corynebacterium glutamicum. Mol \& Gen Genet 212, 105-111.

Zhang, J.-J., Hu, F.-M., Chen, N.-Y. \& Paulus, H. (1990). Comparison of the three aspartokinase isoenzymes in Bacillus subtilis Marburg and 168. $J$ Bacteriol 172, 701-708.

Received 14 July 1995; revised 27 November 1995; accepted 4 December 1995. 